\title{
Crapemyrtle Bark Scale Acanthococcus (=Eriococcus) lagerstroemiae (Kuwana) (Insecta: Hemiptera: Eriococcidae) ${ }^{1}$
}

\author{
Matthew Borden, Xavier Martini, and Adam Dale ${ }^{2}$
}

\section{Introduction}

The crapemyrtle bark scale, Acanthococcus (=Eriococcus) lagerstroemiae (Kuwana), is an invasive felt scale in the family Eriococcidae (or Acanthococcidae, as the taxonomy of this family is still being debated). This group is in the superfamily Coccoidea (scale insects) and the order Hemiptera (true bugs). Felt scales, also called bark scales, are not considered either armored scales or soft scales. As of early 2018, crapemyrtle bark scale has not yet been reported in Florida, however, it has been found in Alabama and Georgia and is expected eventually to spread into Florida. At that time, early detection and treatment will be critical to minimize further spread within the state.

Crapemyrtle bark scale was first observed feeding on crapemyrtle in Richardson, Texas, a Dallas suburb in 2004. Scientists were unsure if a nearly identical species, the azalea bark scale, had begun attacking a new host plant or if this was a newly introduced species. By 2014, DNA and morphological tests helped scientists identify this species as Acanthococcus (=Eriococcus) lagerstroemiae, a felt scale from Asia that is known to feed on crapemyrtle species. The scale insect is widely distributed in Asia, especially China, which is thought to be its native range. It is also found in Japan, Korea, and India (Cai et al. 2015; Wang et al. 2016).

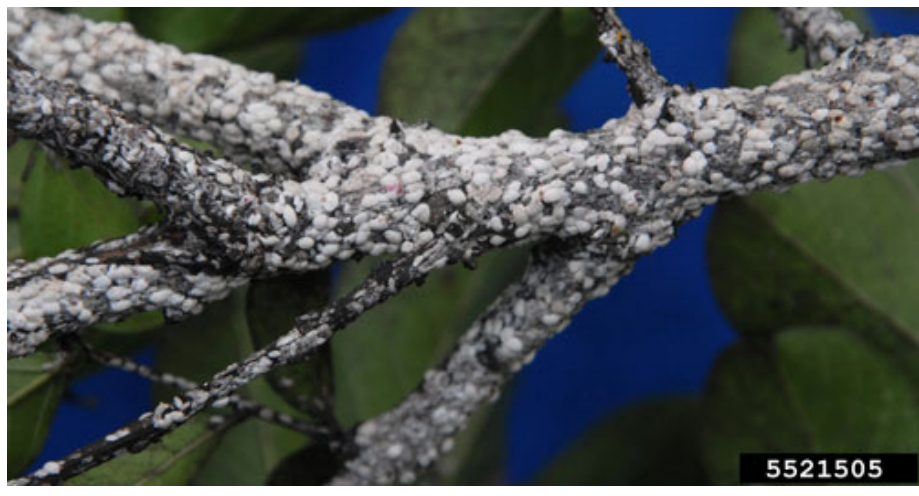

Figure 1. Crapemyrtle bark scale, Acanthococcus lagerstroemiae (Kuwana), infesting young crapemyrtle branches.

Credits: Jim Robbins, University of Arkansas, CES, Bugwood.org

The primary host in North America, crapemyrtle, Lagerstroemia spp., are deciduous flowering trees popular in ornamental landscapes. They are top-sellers in the nursery trade, with the annual wholesale value estimated to be $\$ 66$ million in 2014 (2014 Census of Horticultural Specialties). Based on urban tree inventories of several major cities in the southeastern US, crapemyrtle are among the most common landscape trees planted in this region.

\section{Synonymy}

This species was formerly known as Eriococcus lagerstroemiae Kuwana, so this name may be found in many publications.

1. This document is EENY-711, one of a series of the Department of Entomology and Nematology, UF/IFAS Extension. Original publication date July 2018. Visit the EDIS website at http://edis.ifas.ufl.edu.

2. Matthew Borden, Department of Entomology and Nematology; Xavier Martini, associate professor, UF/IFAS North Florida Research and Education Center; and Adam Dale, assistant professor, Department of Entomology and Nematology; UF/IFAS Extension, Gainesville, FL 32611.

The Institute of Food and Agricultural Sciences (IFAS) is an Equal Opportunity Institution authorized to provide research, educational information and other services only to individuals and institutions that function with non-discrimination with respect to race, creed, color, religion, age, disability, sex, sexual orientation, marital status, national origin, political opinions or affiliations. For more information on obtaining other UF/IFAS Extension publications, contact your county's UF/IFAS Extension office. 
Note: There are a several common names for Lagerstroemia species (e.g., crapemyrtle, crape myrtle, crepe myrtle) and these sometimes carry over to the scale insect's common name, such as crape myrtle bark scale. However, we hold to crapemyrtle bark scale because it is the recognized common name approved by the Entomological Society of America.

\section{Distribution}

As of spring 2018, crapemyrtle bark scale was reported in Alabama, Arkansas, Georgia, Louisiana, Mississippi, New Mexico, North Carolina, Oklahoma, Tennessee, Texas, Virginia, and Washington. Most new infestations have been found in Texas, Oklahoma, and Arkansas. Based on regional climates in the US, scientists have generated predictions of where this insect may spread. Using this information, north Florida is at a moderate to high risk of becoming infested (Wang et al. 2016). Imports of crapemyrtle to these areas should be inspected carefully. Observations of rampant crapemyrtle bark scale infestations in Shanghai, China, further suggest that USDA Zone 9 provides suitable temperatures (Dr. Gary Knox, personal correspondence).

If you find crapemyrtle bark scale in an area not yet reported, specimens must first be confirmed by the FDACS Department of Plant Industry (DPI) so that they can publish a first report and take any necessary regulatory actions. Your local UF/IFAS Extension faculty member and Dr. Gary Knox should be notified, confirmed sightings can also be reported here: https://www.eddmaps.org/cmbs/.

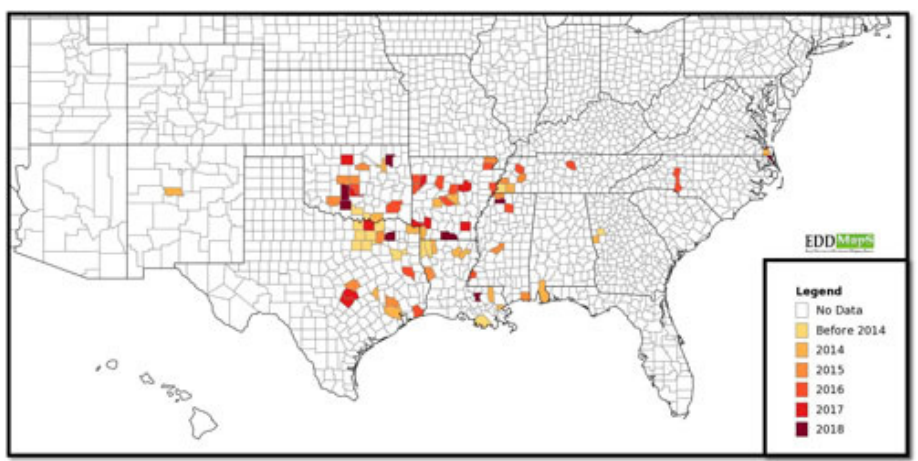

Figure 2. Counties with verified reports of crapemyrtle bark scale, Acanthococcus lagerstroemiae (Kuwana), as of May, 2018. Credits: https://www.eddmaps.org/cmbs/distribution.cfm

\section{Description}

Identification of crapemyrtle bark scale is relatively simple because this is the first and only bark scale known to feed on crapemyrtle in the United States. Heavy infestations are easily seen due to abundant black sooty mold and patches of the white or gray scales on the trunk, branches, and twigs of crapemyrtle.

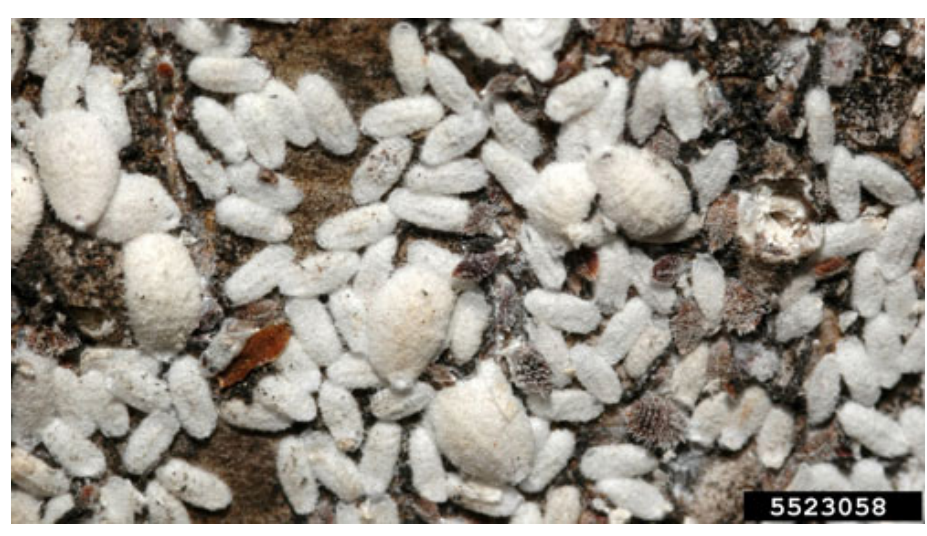

Figure 3. Crapemyrtle bark scale, Acanthococcus lagerstroemiae (Kuwana), close-up of infestation.

Credits: Gary Brooks, Bayer Crop Science, Bugwood.org

On old growth, the scale insects may be aggregated around pruning wounds or branch crotches, whereas distribution is typically more uniform on new growth where the small, pink juveniles (called crawlers) have recently spread and established. More mature scale insects are white to gray and up to $2 \mathrm{~mm}$ in length. A mass of pink eggs may be seen if the white covering is pulled away (Robbins et al. 2014).

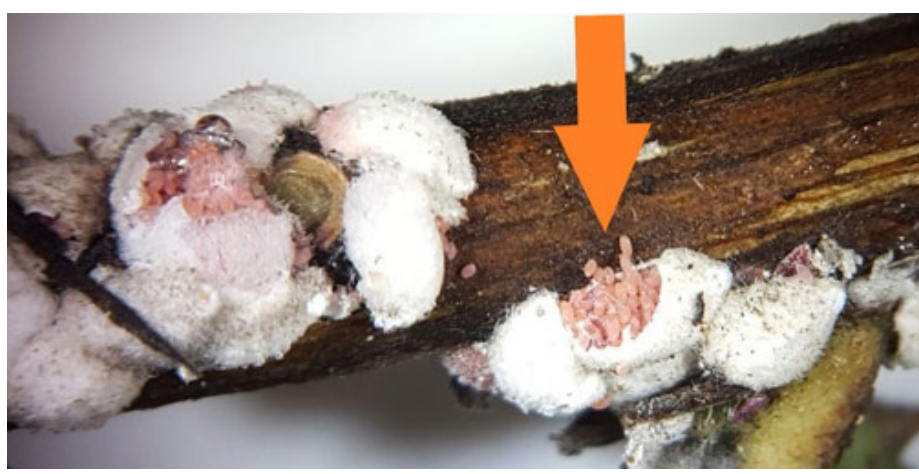

Figure 4. Crapemyrtle bark scale, Acanthococcus lagerstroemiae (Kuwana), adult females and opened egg sacs.

Credits: Helene Doughty, Virginia Polytechnic Institute and State University, Bugwood.org, \#5552233

When scouting large trees, it is important to look not just at the trunk and lower branches. Most of the scales are likely to be on the upper branches and on small twigs. On horizontal branches, they tend to aggregate on the underside, away from sun exposure (Gu et al. 2014). For small plants, inspect all woody parts before purchasing or placing in the landscape. Any crapemyrtle covered in sooty mold should be inspected to see if the cause is bark scale or another insect that also produces honeydew and sooty mold, such as crapemyrtle aphid (Tinocallis kahawaluokalani). These aphids feed on the leaves and tender green shoots, but not woody parts of the plant, whereas crapemyrtle bark scales are very rarely seen on the leaves (Layton 2015).

Monitor for ants moving up and down crapemyrtle trees. Ants have been observed on many trees with crapemyrtle bark scale infestations, but it is not known how they 
interact. Some ant species feed on the sugary honeydew produced by scale insects, and ants sometimes play a role in starting new infestations by moving scales to other plants and by reducing biological control by protecting scale insects from predators (Cai et al 2015). If ants are observed moving up and down crapemyrtle trees it may be helpful to identify any insects they are visiting. Encrustations of scale insects remain on a plant long after the insect has died, so it can be helpful to scrape some scales to determine if they are still living. Dead scales are dry and flakey, but live crapemyrtle bark scales exude a ruby pink color when crushed. Any sharp point can be used to break open the white felt-like covering to see if a female scale is moist and alive, or has clusters of pink eggs present (Layton 2015, Robbins et al. 2014).

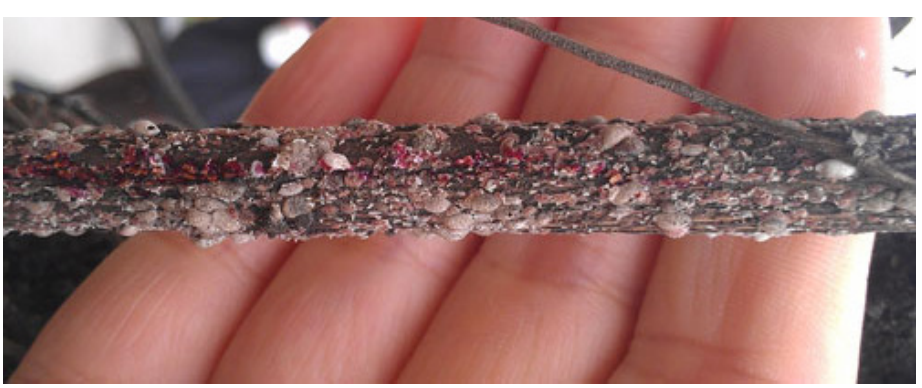

Figure 5. Crapemyrtle bark scale, Acanthococcus lagerstroemiae (Kuwana), bleeds pink when damaged.

Credits: Mengmeng Gu, Texas A\&M AgriLife Extension Service, Bugwood.org, \#5515604

\section{Look-Alike Species}

The azalea bark scale is in the same genus (Acanthococcus) as crapemyrtle bark scale and appears virtually identical. However, this scale has a different host range that is not known to overlap with that of crapemyrtle bark scale. For example, it does not feed on crapemyrtle and is primarily a pest on azaleas (Rhododendron species). It is widely distributed through most of North America (Merchant et al. 2014).

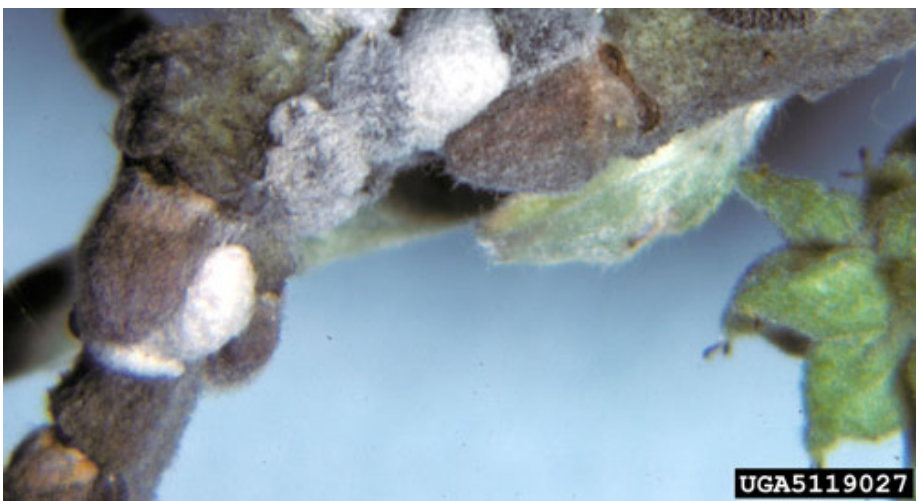

Figure 6. Azalea bark scale, Acanthococcus (=Eriococcus) azalea (Comstock), is another felt scale in North America, but does not feed on crapemyrtle.

Credits: United States National Collection of Scale Insects Photographs, USDA Agricultural Research Service, Bugwood.org

\section{Life Cycle and Biology}

The adult female secretes waxy threads that form a white, felt-like covering around her body and she can lay approximately 100-300 pink eggs underneath this protective covering. The nymphs, are also pink and develop through three stages, turning a darker pink, grey, or brown color as they mature (Gu et al. 2014; Layton 2015). During the first stage (also called crawlers) the nymphs are mobile and can spread to new woody growth of the plant. After the first molt, nymphs lose their legs and become sessile, settling in-place to feed and grow (Wang et al. 2016).

Some nymphs continue through incomplete metamorphosis (do not pupate) to become immobile adult females. Other nymphs form a white, felt-like sac and develop into prepupa and then to pupa further inside, eventually pupating to emerge as tiny, winged adult males (alates). The males are pink, with two long white filaments at the tip of the abdomen, and have no mouthparts. They actively search for adult females. Only the nymphs and adult females feed and secrete honeydew, which can lead to sooty mold growth (Wang et al. 2016).

In the southeast US, there seems to be two to four overlapping generation cycles per year. Any stage of the scale can overwinter, especially the nymphs, which can be found nearly year-round. Activity resumes early in the spring, and the number of crawlers seems to peak around the beginning of summer, and again in late summer (Robbins et al. 2014; Gu et al. 2014). It is unknown how the scale life cycle might adapt in Florida, and more research on the life cycle is in progress to see if there is a predictable pattern.

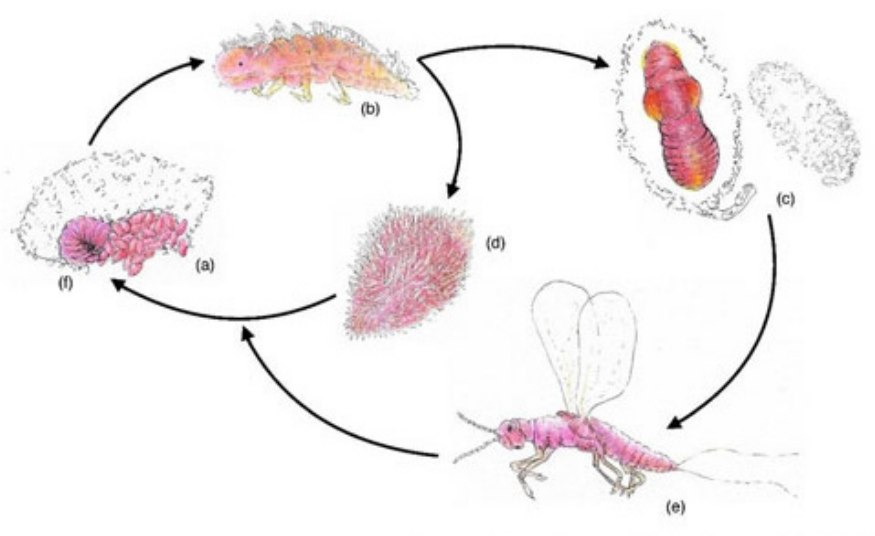

Figure 7. Life cycle of the crapemyrtle bark scale. Nymphs that hatch from the eggs (a) are highly mobile and are called "crawlers" (b). Some nymphs form a white sac and develop into prepupa (c) and then to pupa further inside, before becoming an alate male (e). The females $(d-f)$ do not enter the pre-pupal stage, and start producing eggs following mating with the male.

Credits: April Martin and Xavier Martini, University of Florida 


\section{Hosts}

In the United States, crapemyrtle bark scale has only been found feeding on crapemyrtles, (Myrtales: Lythraceae: Lagerstroemia spp.) and also on American beautyberry (Lamiales: Verbenaceae: Callicarpa americana L.). Lagerstroemia species are native to the same region in Asia as crapemyrtle bark scale and is a preferred host. Callicarpa americana, however, is native to the United States. This new host record is concerning, because American beautyberry is widely distributed in natural areas, roadsides, and urban sites in the southeast. However, it is not yet clear what role this plant may play in the spread of crapemyrtle bark scale.

Although crapemyrtle bark scale has not yet been found on other hosts in North America, it has been reported feeding on a number of other species in Asia and Hungary (see http://scalenet.info for a full list). A few of these are economically or ecologically important and include pomegranate (Punica granatum), Korean boxwood (Buxus microphylla), Chinese hackberry (Celtis sinensis), Japanese persimmon (Diospyros kaki), border privet (Ligustrum obtusifolium), and brambles (Rubus sp.). Continued observation of crapemyrtle bark scale will help us determine if it is a threat to other species in North America (Knox et al. 2018; Wang et al. 2016). Dr. Mengmeng Gu at Texas A\&M is currently conducting research on additional US host plants.

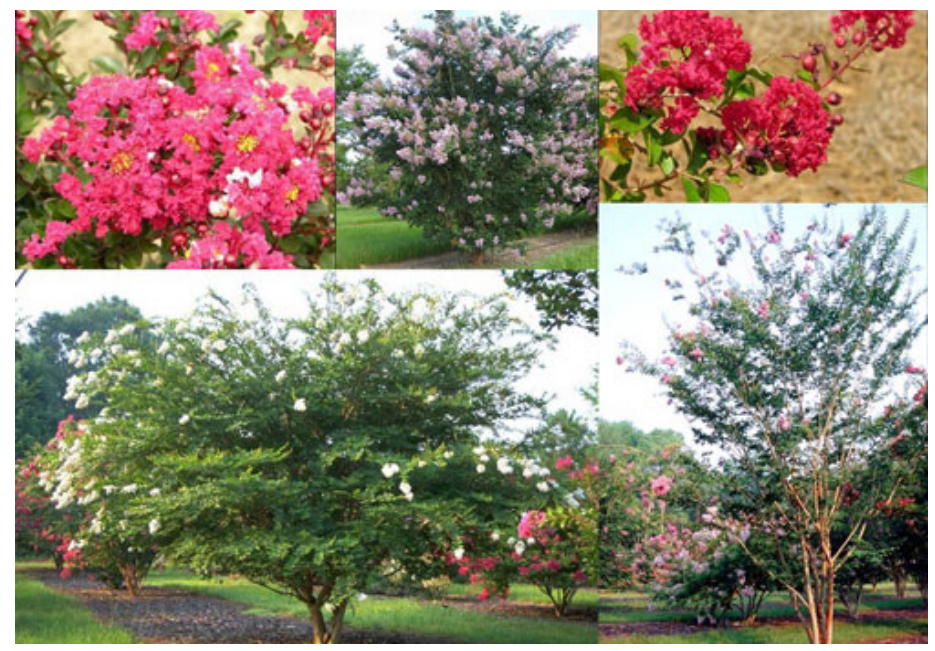

Figure 8. Crapemyrtles of Florida (Lagerstroemia indica and hybrids). Credits: Gary Knox and Ed Gilman, UF/IFAS

\section{Damage}

The primary damage from crapemyrtle bark scale is aesthetic rather than being severely harmful to the tree. Nymphs produce copious amounts of honeydew, a sugary, sticky excrement, which accumulates on any surfaces beneath where the insects feed. Black sooty mold fungi then grow on the honeydew and can result in blackened shrubs, lawn, mulch, concrete, and the crapemyrtle tree itself. Branch dieback and stunted growth has been occasionally observed, but is probably not a primary concern. Leaves coated in sooty mold photosynthesize less, which may translate to reduced tree growth (Layton 2015, Wang et al. 2016). Crapemyrtle is considered a low-maintenance tree and is enormously popular, especially in the urban landscape. Infested trees may force the owner or landscape manager to choose between having an eyesore in their landscape, paying for relatively costly annual scale treatments, or replacing the tree altogether (Layton 2015). Because crapemyrtle is one of the only summer-blooming trees in the landscape, reduction in flower quality and longevity due to heavy infestations is also concerning (Cai et al. 2015).

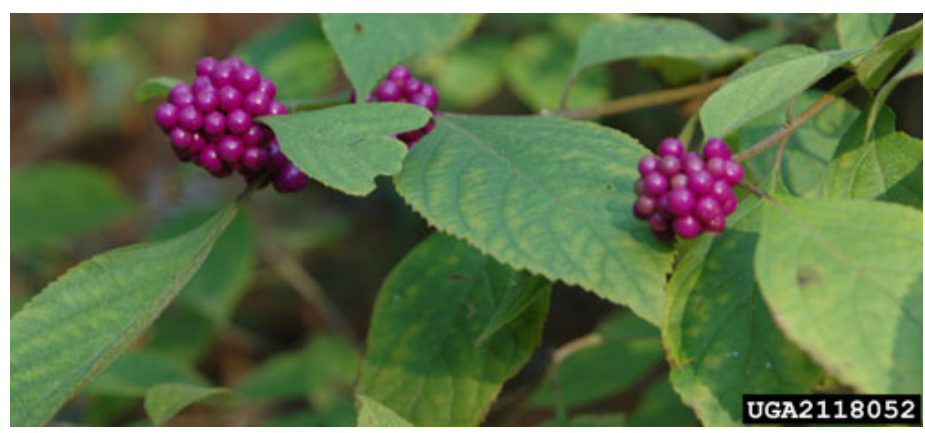

Figure 9. American beautyberry (Callicarpa americana). Credits: Chris Evans, University of Illinois, Bugwood.org

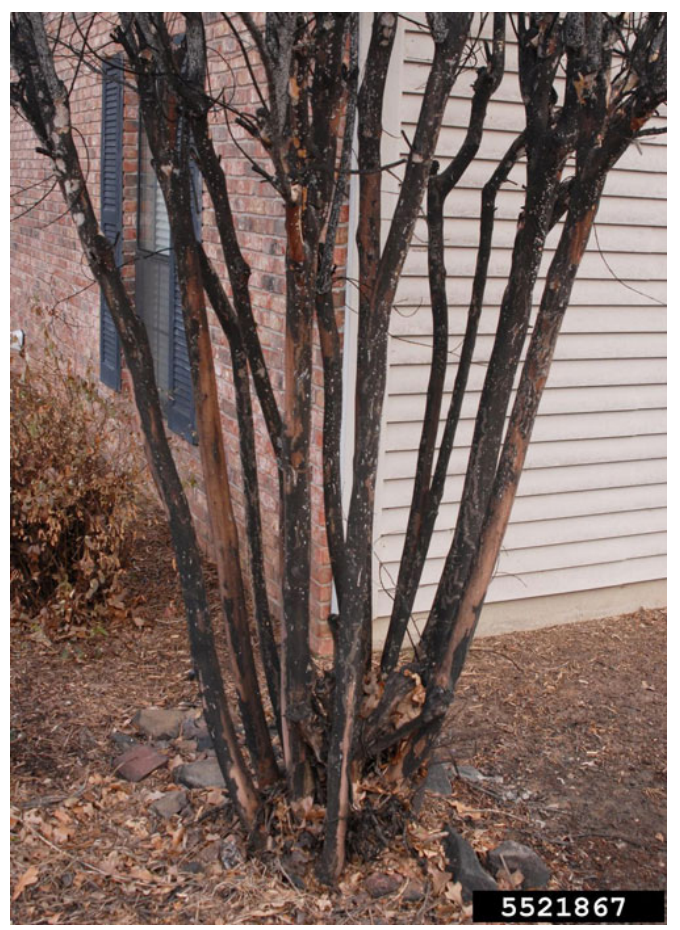

Figure 10. Crapemyrtle bark scale, Acanthococcus lagerstroemiae (Kuwana), infestation with sooty mold covering the bark. Credits: Jim Robbins, University of Arkansas CES, Bugwood.org 


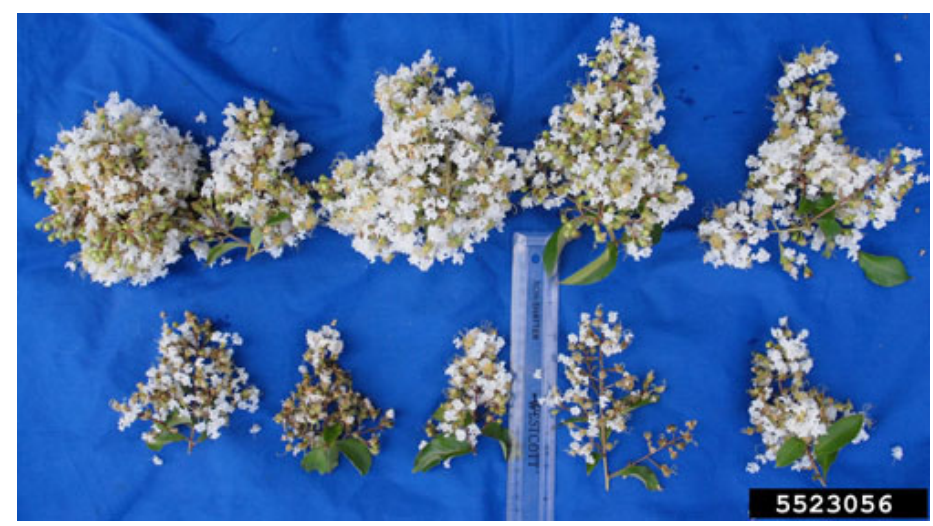

Figure 11. Comparison of normal blossoms (top row) and damaged blossoms (bottom row) caused by crapemyrtle bark scale, Acanthococcus lagerstroemiae (Kuwana).

Credits: Jim Robbins, University of Arkansas CES, Bugwood.org

\section{Management}

\section{Prevention of Spread}

Human-assisted, long distance movement of plant material via the nursery and landscape trades is most likely how this species becomes established in new regions. This may occur when purchasing and moving new plants, or when hauling infested branches away from a site for disposal. Based on observations from Dallas, TX, an established infestation may be able to spread locally at approximately five to 10 miles per year. Local dispersal is likely a combination of the tiny nymphs walking, by wind blowing crawlers to new plants, by human activities, and by bird and mammal movement between trees (Merchant et al. 2014; Wang et al. 2016).

Always inspect crapemyrtles carefully before purchasing or planting, especially if they originated from parts of the southeast where crapemyrtle bark scale is already established. Look for injuries or pruning wounds on the trunk and branches, as scale infestations often start at these sites. Buy from reputable nurseries who are knowledgeable about crapemyrtle bark scale and inspect outgoing plants (Robbins et al. 2014; Layton 2015).

If an infested plant is found in a new area, it may be appropriate to destroy the plant rather than attempt treatment. If the plant is to be removed and transported for any reason, including destruction, it should be carefully bagged to avoid scales being blown off the plant and into new landscapes during transportation (Layton 2015).

\section{Mechanical Control}

Prior to treatment of heavily infested plants, it can be helpful to wash the reachable branches with a mild soap solution and a soft scrubbing brush. Although this alone will not control an infestation, it can physically remove many female scales and egg masses, making the chemical treatment more effective (Gu et al. 2014; Robbins et al. 2014). Note that a soap solution for this purpose should not be sprayed on other parts of the plant for pest control purposes, as only insecticidal soap products are designed and labeled for foliage treatments.

\section{Cultural Control}

Some observations suggest that crapemyrtle bark scale infestations may be correlated to shade levels, adding credence to the recommendation that crapemyrtles should be planted in full-sun locations (Cai et al. 2015). In the future, plant selection may play an important role in management. So far, no cultivars of crapemyrtle are known to have high levels of resistance to the scale. Some cultivars, however, that have been observed with high infestations include 'Tuscarora,' 'Lipan', 'Pink Ruffles,' 'Tuskegee, 'Acoma,' 'Velma', 'Choctaw', and 'New Orleans' (Cai et al. 2015). Observations from McKinney, TX suggest that Lagerstroemia fauriei and Lagerstroemia indica x Lagerstroemia fauriei hybrids also suffer high infestations (Gu et al. 2014). Much research is needed before cultivar or hybrid selection can be incorporated into management plans. Because crapemyrtle bark scale is not yet established in Florida, any discovered populations should be eradicated as soon as possible. Plant removal and chemical control are the most effective ways to do this.

\section{Biological Control}

Several predators serve as biological control for crapemyrtle bark scale in the southeast. The most effective of these seem to be twice-stabbed lady beetles, such as Chilocorus stigma and Chilocorus cacti (Cai et al. 2015, Wang et al. 2016) However, despite the predation by these and other lady beetle species, their control often comes too late in the season to prevent damage from the scales and sooty mold ( $\mathrm{Gu}$ et al. 2014). Lady beetles always lay eggs in the presence of prey, therefore bark scale has to be there first before attracting lady beetles. In addition, biological control will not eradicate an invasive population. Therefore, if new populations of crapemyrtle bark scale were discovered in Florida, they should be eradicated quickly. If left to wait for biological control, the infestation may be allowed time to spread further. 


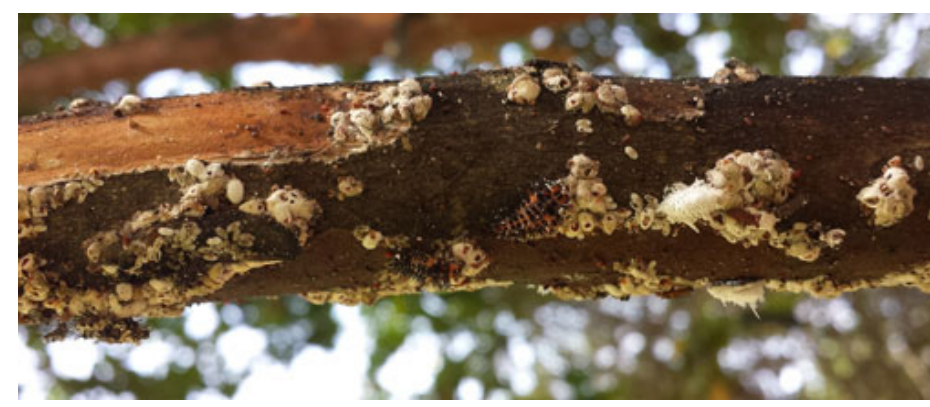

Figure 12. I species of lady beetle larvae feeding on an infestation of Acanthococcus lagerstroemiae (Kuwana).

Credits: Erfan Vafaie, Texas A\&M AgriLife Extension

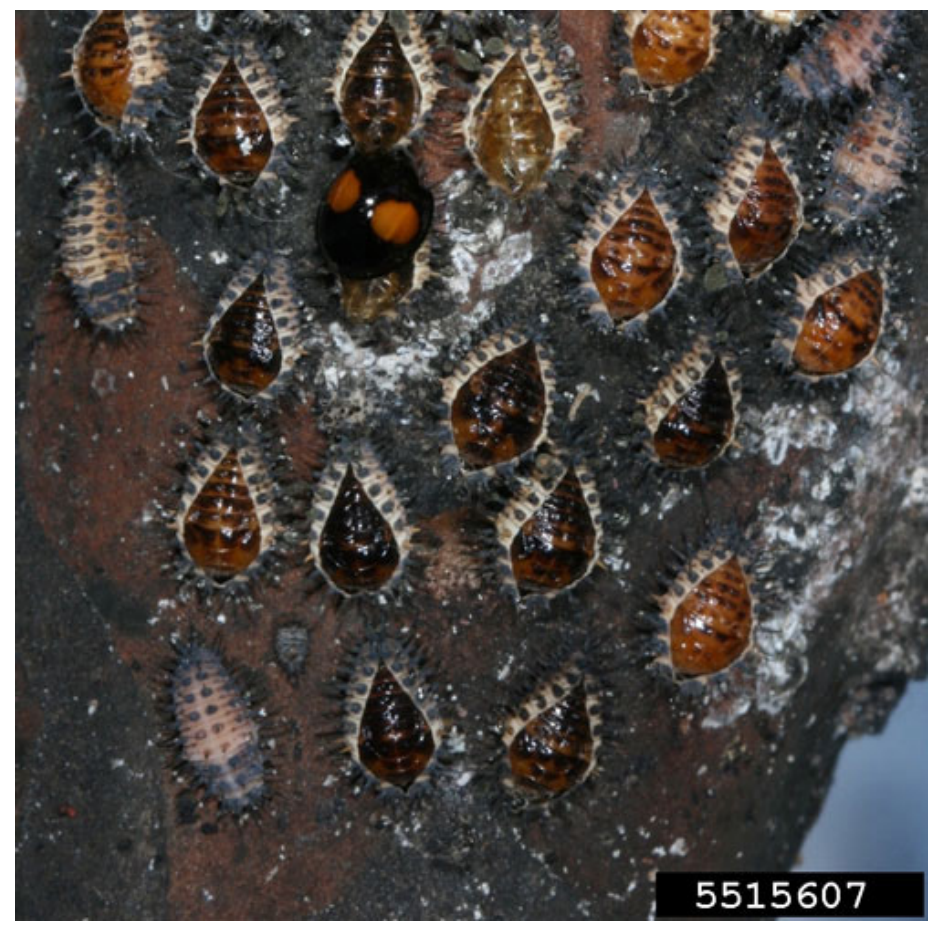

Figure 13. One adult, several pre-pupae, and many pupae of twicestabbed lady beetle after feeding on an infestation of Acanthococcus lagerstroemiae (Kuwana).

Credits: Michael Merchant, Texas A\&M AgriLife Extension Service, Bugwood.org

\section{Chemical Control}

Because crapemyrtle bark scale is not yet found in Florida, any discovered populations should be eradicated as soon as possible to slow further spread within the state. Plant removal and chemical control are the most effective ways to do this. Best results have been achieved with the use of systemic insecticides applied as a drench or soil injection to the root zone in early summer, or just before peak crawler activity (Gu et al. 2014, Layton 2015). Please refer to the crapemyrtle bark scale EDIS publication (UF/IFAS EDIS) for current management recommendation in Florida, or consult your local UF/IFAS Extension office.
If you plan to use insecticides, be sure to check with your local county Extension faculty member regarding any restrictions on use of these pesticides as some may require an applicator's license! The current chemical recommendations may be extremely toxic to bees and other pollinators that feed on crapemyrtle pollen. Applications should not be made if the tree is in flower, and all pollinator protection requirements on the label must be followed to minimize risk. Be careful not to make an infestation worse by applying pesticides that have not been recommended by authorities. Studies show that some common pesticides (e.g., pyrethroids) cause scale populations to increase. This is likely because these pesticides are not very effective against the scale insect, but are highly toxic to lady beetle predators. Integrated pest management (IPM) plans to control crapemyrtle bark scale are still being developed, but may incorporate the use of certain reduced-risk insecticides that have been successfully used to control other scales, resistant crapemyrtle cultivars, and biological control.

\section{Additional Resources}

Crapemyrtle Bark Scale Resource Website (StopCMBS)

Crapemyrtle Bark Scale Early Detection and Distribution Mapping System (EDDMapS)

Department of Plant Industry (DPI) Sample Submission

Managing Scale Insects on Ornamental Plants

UF/IFAS Extension: Crapemyrtle Publications

\section{Selected References}

2014 Census of Horticultural Specialties. Available online: https://www.agcensus.usda.gov/Publications/ 2012/

Online_Resources/Census_of_Horticulture_Specialties/ (5 May 2018).

Borden MA, Dale AG. 2018. Crapemyrtle bark scale, Acanthococcus (=Eriococcus) lagerstroemiae. Florida First Detector (27 March 2018).

Cai X, Dou H, Gu M, Merchant M, Vafaie E. 2015. Update on crapymyrtle bark scale. Proceedings of the 2015 Annual Meeting of the International Plant Propagators' Society. 1140: $415 \hat{\mathrm{A}}-418$.

Chen Y, Merchant M, Vafaie E, Gu M, Robbins J. 2017. Crape myrtle bark scale management updates. Louisiana State University Ag Center (10 May 2018). 
GarcÃa Morales M, Denno BD, Miller DR, Miller GL, Ben-Dov Y, Hardy NB. 2016. ScaleNet: A literature-based model of scale insect biology and systematics. Database. doi: 10.1093/database/bav118. http://scalenet.info. See: Acanthococcus lagerstroemiae (Kuwana) 1907 (10 May 2018).

Gu M, Merchant M, Robbins J, Hopkins J. 2016. Crape myrtle bark scale: A new exotic pest, EHT-049. The Texas A\&M University System, Texas A\&M AgriLife Extension Service (10 May 2018).

Knox G, Gu M, Merchant M, Vafaie E, Chen Y, Robbins J. 2018. Biology and potential impacts of the emerging pest, crapemyrtle bark scale. Proceedings of the Southern Nursery Association Research Conference. 62: In press.

Layton B. 2015. Crape Myrtle Bark Scale Identification and Control, Publication 2938. Mississippi State University Extension (10 May 2018).

Merchant ME, Gu M, Robbins J, Vafaie E, Barr N, Tripodi AD, Szalanski AL. 2014. Discovery and spread of Eriococcus lagerstroemiae Kuwana (Hemiptera: Eriococcidae), a new invasive pest of crape myrtle, Lagerstroemia spp. (10 May 2018).

Robbins J, Hopkins J, Merchant M, Gu M. 2014. Crapemyrtle Bark Scale: A New Insect Pest, FSA7086. University of Arkansas Cooperative Extension .

Vafaie EK., and Knight CM. 2017. Bark and Systemic Insecticidal Control of Acanthococcus (=Eriococcus)lagerstroemiae (Crapemyrtle Bark Scale) on Landscape Crapemyrtles, 2016. Arthropod Management Tests. 42: 1-2. doi: 10.1093/amt/tsx130.

Wang Z, Chen Y, Gu M, Vafaie E, Merchant M, Diaz R. 2016. Crapemyrtle bark scale: A new threat for crapemyrtles, a popular landscape plant in the U.S. Insects. 7: 33-34. doi: 10.3390/insects7040078. 